\title{
Central obesity increases the risk of type 2 diabetes mellitus among urban adults
}

\author{
Julianty Pradono*, Nunik Kusumawardani*, and Delima**
}

\begin{abstract}
\section{BACKGROUND}

In Indonesia the number of persons with type 2 diabetes mellitus (T2DM) was 8.5 million in 2013, and is estimated to be 11.8 million in 2030. The aim of this study was to determine the major risk factors associated with $\mathrm{T} 2 \mathrm{DM}$ prevalence in urban aged $\geq 15$ years.
\end{abstract}

\section{METHODS}

An observational study with cross-sectional design was used with the data from Riskesdas 2007 and 2013 on population aged $\geq 15$ years. Total respondents were 294,352 (2007) and 368,281 (2013). Data were collected by trained personnel through interviews, blood pressure and anthropometry measurements, and blood glucose and lipid tests. Odds ratio (OR) was used to test the relationship between T2DM and a number of other variables. Multiple logistic regression analysis was obtained to determine the main risk factor associated with T2DM prevalence.

\section{RESULTS}

Type 2 diabetes mellitus prevalence increased from $2.3 \%$ (2007) to $2.5 \%$ (2013). T2DM tended to be increased in the younger age groups. Low education, middle-to-high economic status, less physical activity, smoking $\geq 200$ cigarettes, and high risk blood lipid levels were strongly associated with T2DM prevalence. The main risk factors were inadequate physical activity (2007: OR 1.9;95\% CI:1.16-2.98 and 2013: OR 2.44;95\% CI: 1.57-3.78) and central obesity (2007: OR 1.8;95\% CI:0.99-3.10, and 2013:OR 3.84; 95\% CI: 2.49-5.93) after controlling for age, gender, employment and economic status.

\section{CONCLUSIONS}

Type 2 diabetes mellitus prevalence in the population aged $\geq 15$ years increased within 5 years. Lack of physical activity and central obesity were the major risk factors of T2DM prevalence in urban adults.

Keywords: Physical activity, central obesity, type 2 diabetes mellitus, adults, urban areas
*Public Health Intervention

Technology Center, HRDA-MOH RI

**Clinical Epidemiology and Applied Health Technology Center, HRDAMOH RI

Correspondence:

Dr. dr. Julianty Pradono, MS.

Jl.Dewi Sartika no.292

Jakarta Timur

Mobile: +62812 1004523

Email:.jpradono@yahoo.com

Univ Med 2015;34:187-96

DOI: 10.18051/UnivMed.2016.v35.187-196 pISSN: 1907-3062 / eISSN: 2407-2230

This open access article is distributed under a Creative Commons Attribution-Non Commercial-Share Alike 4.0 International License 


\section{Obesitas sentral meningkatkan kejadian diabetes melitus tipe 2 pada orang dewasa di perkotaan}

\section{ABSTRAK}

\section{LATAR BELAKANG}

Di Indonesia jumlah penduduk dengan diabetes melitus tipe 2 (DM2) adalah 8,5 juta orang pada tahun 2013, dan diperkirakan menjadi 11,8 juta pada tahun 2030. Tujuan penelitian ini untuk mendapatkan faktor risiko utama yang berhubungan dengan kejadian DM pada penduduk umur $\geq 15$ tahun di perkotaan.

\section{METODE}

Penelitian observasional dengan desain potong lintang digunakan dengan data Riskesdas 2007 dan 2013 pada penduduk umur $\geq 15$ tahun. Jumlah sampel sebanyak 294.352 (2007) dan 368.281 responden (2013). Pengumpulan data oleh enumerator terlatih melalui wawancara, pengukuran tekanan darah, antropometri, dan pemeriksaan darah (kadar glukosa darah dan lipid darah). Odds rasio (OR) digunakan untuk menetukan hubungan antara T2DM dan beberapa variabel. Regresi logistik ganda digunakan untuk menentukan faktor risiko utama yang mempunyai hubungan dengan kejadian DM2.

\section{HASIL}

Prevalensi DM2 meningkat dari 2,3\% (2007) menjadi 2,5\% (2013). Ada kecendrungan peningkatan DM2 pada umur lebih muda. Penduduk dengan pendidikan rendah, status ekonomi mampu, kurang aktivitas fisik, merokok $\geq 200$ batang, dan kadar lipid darah berisiko mempunyai hubungan kuat dengan kejadian DM2. Sedangkan faktor risiko utama adalah kurang aktivitas fisik (2007: OR 1,9;95\% CI:1,16-2,98 dan 2013: OR 2,44;95\% CI: 1,57-3,78) dan obesitas sentral (2007: OR 1;8; 95\% CI:0,99-3,10, dan 2013: OR 3,84;95\% CI: 2,49-5,93) setelah dikontrol oleh umur, jenis kelamin, pekerjaan dan status ekonomi.

\section{KESIMPULAN}

Terjadi peningkatan prevalensi DM2 pada penduduk umur $\geq 15$ tahun dalam kurun waktu 5 tahun di perkotaan. Kurang aktivitas fisik dan obesitas sentral merupakan faktor risiko utama dari kejadian DM2 pada orang dewasa di perkotaan.

Kata kunci: Aktivitas fisik, obesitas sentral, diabetes melitus tipe 2, orang dewasa, perkotaan

\section{INTRODUCTION}

The number of persons with type 2 diabetes mellitus (T2DM) is expected to become a burden in adults, particularly in especially developing countries. In 2013, there were 382 million people with diabetes, and this number is projected to become 592 million in 2035. The majority (77\%) of people with diabetes live in low and middle income countries. ${ }^{(1)}$ The International Diabetes Federation (IDF) estimates that in 2030 a total of 398 million (7.1\%) will have impaired glucose tolerance (IGT) and that DM will cause 4.9 million deaths in 2014 , or that every seven seconds one person will die from DM. ${ }^{(2)}$

In the Asia Pacific region, T2DM constitutes a health problem. Undiagnosed cases or case with delayed diagnosis and low levels of monitoring are frequently associated with increased risk of microvascular and cardiovascular disease, disabilities, and premature deaths. ${ }^{(3,4)}$ 
Although Indonesia does not belong to the 10 countries with the highest diabetes prevalence in the world, as a country with a large population, in 2013 it was number 7 in rank, with 8.5 million persons with T2DM, which is projected to become 11.8 million in 2030. ${ }^{(5)}$ The results of the Basic Health Research (Riset Kesehatan Dasar, Riskesdas) of 2007 and 2013 showed that the prevalence of T2DM in Indonesia, as obtained by interviews, also tended to increase from $1.1 \%$ (6) to $2.1 \%$. $^{(7)}$

Diabetes mellitus is a life-long chronic metabolic disease that is a risk factor for cardiovascular disease, a major cause of death. Uncontrolled diabetes mellitus results in various complications, such as diabetic foot, neuropathy, retinopathy, chronic renal disease, coronary heart disease, and stroke. ${ }^{(8)}$

The results of several studies have indicated a number of unmodifiable and modifiable factors that increase the risk of DM. Unmodifiable risk factors include ethnicity, family history of diabetes, age, history of delivery of infants of $>4 \mathrm{~kg}$ body weight, and history of gestational DM. Modifiable risk factors comprise overweight, low physical activity level, hypertension, dyslipidemia, and unhealthy diet (high in sugar and low in fiber) ${ }^{(6,9)}$

Awareness of the increased incidence of T2DM and measures to prevent T2DM by controlling the risk factors need to be promoted. For this purpose, the prevalence and the determining risk factors of T2DM should be continuously investigated and analyzed from year to year. To date no information was available on studies showing a tendency of increased T2DM incidence in Indonesia adults residing in urban areas. The objective of this study was to determine a tendency of increased prevalence of T2DM and its determining risk factors in urban adults.

\section{METHODS}

\section{Research design}

This research was part of the Riskesdas 2007 and 2013 studies. This was a non- interventional cross-sectional study conducted from September to November 2007 and from August to October 2013.

\section{Study subjects}

The respondents were household members aged $\geq 15$ years, residing in urban areas, of households selected as samples in Riskesdas 2007 or Riskesdas 2013. The inclusion criteria were residents $\geq 15$ years old, males and females, agreeing to be interviewed and to be subjected to blood sampling. The number of respondents fullfilling the inclusion criteria in 2007 and 2013 were 294,352 and 368,281 respectively.

\section{Interviews}

Interviews were performed using a questionnaire comprising items on sociodemographic characteristics, past history of disease, and high risk behavioral factors. The questions focused on the respondents having been diagnosed by health personnel as suffering from T2DM, on the T2DM symptom triad (polyphagia, polydipsia, and polyuria) and on current use of antidiabetics or insulin injections.

\section{Measurements}

Of the anthropometrical measurements, weight was measured in "kg" using personal scales, and height was measured in " $\mathrm{cm}$ " using a stadiometer. Abdominal circumference was measured in "cm" using a measuring tape. Body mass index (BMI) was calculated from the formula: $\mathrm{BMI}\left(\mathrm{kg} / \mathrm{m}^{2}\right)=$ weight $(\mathrm{kg}) /\left[\right.$ height $\left.(\mathrm{m})^{2}\right]$. Blood pressure was measured using a digital sphygmomanometer.

\section{Laboratory analysis}

Blood samples from the cubital vein were drawn after the respondents had fasted for 10-12 hours. Fasting and 2-hour postload blood glucose concentrations were determined by electroenzymatic methods. Blood lipid concentration was determined at the Health Research and Development Agency (HRDA, Balitbangkes) integrated laboratory, using the 
Cobas 6000 Roche analyzer and the C501module kit on enzymatic colorimetric principles. ${ }^{(10,11)}$ Blood examinations consisted of fasting glucose measurement and determination of blood glucose 2 hours after loading with a solution of $75 \mathrm{~g}$ glucose in $250 \mathrm{ml}$ water, total cholesterol, high density lipoprotein (HDL), low density lipoprotein (LDL), and triglyceride concentrations.

Diabetes mellitus type 2 was diagnosed according to the 2011 guidelines of the American Diabetes Association (ADA). ${ }^{(12)}$ The T2DM diagnostic criteria were considered to be met if: 1) random plasma glucose concentration was $\geq 200 \mathrm{mg} / \mathrm{dL}$ and the classical symptoms of T2DM were present, such as polyuria, polydipsia, polyphagia, and unexplained weight loss; 2) fasting plasma glucose of $\geq 126 \mathrm{mg} \%$ with classical T2DM symptoms; 3) 2-hour postload glucose $\geq 200 \mathrm{mg} / \mathrm{dL}$.

Blood lipid concentration was referenced to the normal values according to the National Cholesterol Education Program (NCEP)-Adult Treatment Panel (ATP) III. ${ }^{(13)}$ Normal total cholesterol was taken as $<200 \mathrm{mg} / \mathrm{dL}$, and abnormal total cholesterol concentrations included the criteria borderline (200-239 mg/dL) and high $(\geq 240 \mathrm{mg} / \mathrm{dL}$ ). In the analysis, the limit of 240 $\mathrm{mg} / \mathrm{dL}$ was taken. The normal HDL value in males and females was $\geq 40 \mathrm{mg} / \mathrm{dL}$ and the optimal LDL value was $<100 \mathrm{mg} / \mathrm{dL}$. Based on the reference, the category of near optimal/above optimal was $100-129 \mathrm{mg} / \mathrm{dL}$, borderline high was $130-159 \mathrm{mg} /$ $\mathrm{dL}$, high had a value of $160-189 \mathrm{mg} / \mathrm{dL}$, and very high had a value of $\geq 190 \mathrm{mg} / \mathrm{dL}$. In the analysis, LDL values were categorized as $<160 \mathrm{mgdL}$ and $\geq 160 \mathrm{mg} / \mathrm{dL}$. The normal triglyceride value was $<150 \mathrm{mg} / \mathrm{dL}$. There were several triglyceride categories, i.e. borderline high with the values of $150-199 \mathrm{mg} / \mathrm{dL}$, high with $200-499 \mathrm{mg} / \mathrm{dL}$ and very high with $\geq 500 \mathrm{mg} / \mathrm{dL}$. In the analysis, the triglyceride limits were taken as $<200 \mathrm{mg} / \mathrm{dL}$ and $\geq 200 \mathrm{mg} / \mathrm{dL}$.

\section{Data analysis}

Data analysis was performed descriptively to describe the prevalence distribution of T2DM based on several variables. The odds ratio was used to test for a relationship between T2DM and a number of other variables. Furthermore, multiple logistic regression analysis was used to obtain models of T2DM risk factors.

\section{Ethical clearance}

The conduct of Riskesdas 2007 and Riskesdas 2013 had obtained ethical approval from the Ethical Commission of the Health Research and Development Agency, Ministry of Health, Republic of Indonesia (NHRD-MOH $\mathrm{RI})$.

\section{RESULTS}

The prevalence of T2DM based on symptoms (DM triad) and blood glucose testing (fasting and 2 hour postload) in persons aged $\geq 15$ years increased from $2.3 \%$ in 2007 to $2.5 \%$ in 2013. The prevalence of T2DM increased with advancing age up to 55-64 years, then tended to decrease up to 75 years or above. This was found in both the findings of the year 2007 and 2013. When comparing these two studies, there was a tendency for the T2DM prevalence to increase, particularly in the younger age groups.

The prevalence of T2DM was higher in persons with low education and middle-to-high economic status (quintiles 3-5) in comparison with high education and low economic status (quintiles 1-2). Working males had more frequently $\mathrm{T} 2 \mathrm{DM}$ in comparison with nonworking females in 2007, but the opposite occurred in 2013 (Table 1).

The prevalence of T2DM was higher in persons with inadequate physical activity, in smokers with a Brinkman index of 200 cigarettes or more, in ex-smokers, consumers of fruits and vegetables of 3 servings or more per day, consumers of sweets and consumers of coffee of less than once daily in 2007 and 2013. On the other hand, the prevalence of T2DM was higher in 2007, but lower in 2013, in persons who consumed fatty foods once daily or more (Table $1)$. 
Table 1. Relationship between T2DM and sociodemographic characteristics and behavior of respondents

\begin{tabular}{|c|c|c|c|c|c|c|}
\hline \multirow{3}{*}{ Characteristic } & \multicolumn{6}{|c|}{ T2DM } \\
\hline & \multicolumn{3}{|c|}{ Year 2007} & \multicolumn{3}{|c|}{ Y ear 2013} \\
\hline & $\%$ & $\mathbf{p}$ & OR & $\%$ & $\mathbf{P}$ & OR \\
\hline \multicolumn{7}{|l|}{ Age group } \\
\hline $15-24$ yx & 0.3 & 0.000 & & 0.6 & 0.000 & \\
\hline $25-34$ yr & 0.8 & & & 0.8 & & \\
\hline $35-44$ yx & 1.6 & & & 1.8 & & \\
\hline $45-54 y^{n}$ & 4.1 & & & 5.0 & & \\
\hline $55-64 y^{x}$ & 6.6 & & & 7.5 & & \\
\hline $65-74 \mathrm{yx}$ & 6.3 & & & 7.0 & & \\
\hline $75+y r$ & 5.8 & & & 5.2 & & \\
\hline \multicolumn{7}{|l|}{ Gender } \\
\hline Male & 2.5 & 0.213 & $0.9(0.7-1.1)$ & 2.3 & 0.000 & $1.2(1.1-1.3)$ \\
\hline Female & 2.2 & & & 2.7 & & \\
\hline \multicolumn{7}{|l|}{ Education } \\
\hline$\leq$ Junior high school & 2.4 & 0.413 & $0.9(0.7-1.1)$ & 2.8 & 0.000 & $0.8(0.7-08)$ \\
\hline Seni or high schoolt & 2.2 & & & 2.2 & & \\
\hline \multicolumn{7}{|l|}{ Empil oyment } \\
\hline Unem ployed & 2.0 & 0.021 & $1.3(10-1.6)$ & 3.0 & 0.000 & $0.7(0.7-0.8)$ \\
\hline Employed & 2.6 & & & 2.2 & & \\
\hline \multicolumn{7}{|l|}{ Quintile } \\
\hline Quintiles1-2 & 1.8 & 0.001 & $1.5(12-1.9)$ & 1.8 & 0.000 & $1.4(1.4-15)$ \\
\hline Quintiles 3-5 & 2.6 & & & 2.6 & & \\
\hline \multicolumn{7}{|l|}{ Behavio r } \\
\hline \multicolumn{7}{|l|}{ Physical acti vity } \\
\hline Adequate & 1.9 & 0.000 & $1.7(1.4-2.1)$ & 2.2 & 0.000 & $1.5(15-16)$ \\
\hline Inadequate & 3.2 & & & 3.4 & & \\
\hline \multicolumn{7}{|l|}{ Brinktu an index } \\
\hline$<200$ ci garettes & 1.7 & 0.014 & $1.8(1.1-2.8)$ & 1.6 & 0.000 & $2.1(19-23)$ \\
\hline$>200$ cigarettes & 3.1 & & & 3.3 & & \\
\hline \multicolumn{7}{|l|}{ Sm oking behavior } \\
\hline Non-smoker & 2.1 & 0.000 & & 2.6 & 0.000 & \\
\hline Active smoker & 2.3 & & & 1.9 & & \\
\hline Ex-smoker & 5.3 & & & 5.6 & & \\
\hline \multicolumn{7}{|c|}{ Consumption of fruits and vegetables } \\
\hline$\geq 3$ servingg/day & 2.5 & 0.214 & $0.9(0.7-1.1)$ & 2.7 & 0.000 & $0.9(0.8-09)$ \\
\hline$<3$ servings/day & 2.2 & & & 2.4 & & \\
\hline \multicolumn{7}{|l|}{ Sweets } \\
\hline$<1 \mathrm{x} /$ day & 3.7 & 0.000 & $0.4(03-0.5)$ & 3.4 & 0.000 & $0.5(05-05)$ \\
\hline$\geq 1 \mathrm{x} / \mathrm{day}$ & 1.6 & & & 1.8 & & \\
\hline \multicolumn{7}{|l|}{ Fatty foods } \\
\hline$<1 \mathrm{x} /$ day & 2.2 & 0.051 & $1.3(10-1.7)$ & 2.7 & 0.000 & $0.9(0.8-09)$ \\
\hline$\geq 1 x / d a y$ & 2.9 & & & 2.3 & & \\
\hline \multicolumn{7}{|l|}{$\mathrm{C}$ offee consum pti on } \\
\hline$<1 \mathrm{x} /$ day & 2.5 & 0.013 & $0.7(0.6-0.9)$ & 2.7 & 0.000 & $0.7(0.7-0.8)$ \\
\hline$\geq 1 \mathrm{x} /$ day & 1.9 & & & 2.2 & & \\
\hline
\end{tabular}

In general, higher fasting and 2-hour postload blood glucose concentrations were strongly associated with the incidence of T2DM. In 2007 no fasting blood glucose concentrations were collected, so that this finding could not be compared. High- risk blood lipid concentrations (total cholesterol, HDL, LDL, triglycerides) had a strong association with the incidence of T2DM 
Table 2. Relationship between T2DM and biological risk factor

\begin{tabular}{|c|c|c|c|c|c|c|}
\hline \multirow{3}{*}{ Biobgical risk factor } & \multicolumn{6}{|c|}{ T2DM } \\
\hline & \multicolumn{3}{|c|}{ Year 2007} & \multicolumn{3}{|c|}{ Year 2013} \\
\hline & $\%$ & $\mathbf{p}$ & OR & $\%$ & $\mathbf{p}$ & OR \\
\hline \multicolumn{7}{|l|}{ F asting blood glucose } \\
\hline$<100 \mathrm{mg} \%$ & - & & & 0.9 & 0.000 & \\
\hline $100-125 \mathrm{mg} \%$ & - & & & 2.7 & & \\
\hline$>126 \mathrm{mg} \%$ & - & & & 23.0 & & \\
\hline \multicolumn{7}{|l|}{ 2-hr postpr andial blood glucose } \\
\hline$<140 \mathrm{mg} \%$ & 3.6 & 0.814 & & 1.1 & 0.000 & \\
\hline $140-<200 \mathrm{mg} \%$ & 0.0 & & & 2.7 & & \\
\hline$=200 \mathrm{mg} \%$ & 0.0 & & & 20.3 & & \\
\hline \multicolumn{7}{|l|}{ T otal cholester ol } \\
\hline$<240 \mathrm{mg} \%$ & 2.2 & 0.000 & $1.4(1.1-1.9)$ & 2.4 & 0.000 & $3.3(2.8-39)$ \\
\hline$=240 \mathrm{mg} \%$ & 3.1 & & & 7.3 & & \\
\hline \multicolumn{7}{|l|}{$\mathrm{HDL}$} \\
\hline Not at risk & 2.0 & 0.000 & $1.4(1.1-1.8)$ & 2.6 & 0.242 & $0.9(09-10)$ \\
\hline At risk & 2.8 & & & 2.5 & & \\
\hline \multicolumn{7}{|l|}{ LDL } \\
\hline$<160 \mathrm{mg} \%$ & 2.1 & 0.000 & $1.5(12-1.9)$ & 2.3 & 0.000 & $2.7(23-3.1)$ \\
\hline$=160 \mathrm{mg} \%$ & 3.2 & & & 5.9 & & \\
\hline \multicolumn{7}{|l|}{ Triglycerides } \\
\hline$<200 \mathrm{mg} \%$ & - & & & 2.4 & 0.000 & $2.6(22-3.1)$ \\
\hline$=200 \mathrm{mg} \%$ & - & & & 6.0 & & \\
\hline \multicolumn{7}{|l|}{ BMI } \\
\hline$<27 \mathrm{~kg} / \mathrm{m}^{2}$ & 2.0 & 0.000 & $2.3(1.8-2.9)$ & 2.2 & 0.000 & $1.7(16-18)$ \\
\hline$=27 \mathrm{~kg} / \mathrm{m}^{2}$ & 4.4 & & & 3.7 & & \\
\hline \multicolumn{7}{|l|}{ Abdominal circumference } \\
\hline Not at risk & 1.7 & 0.000 & $2.5(2.0-3.1)$ & 1.9 & 0.000 & $2.3(22-2.4)$ \\
\hline At risk & 4.2 & & & 4.4 & & \\
\hline \multicolumn{7}{|l|}{ Hypertension } \\
\hline No & 1.5 & 0.000 & $2.3(1.8-2.9)$ & 1.5 & 0.000 & $3.5(3.4-3.7)$ \\
\hline Yes & 3.4 & & & 5.2 & & \\
\hline \multicolumn{7}{|l|}{ Mental disturbances } \\
\hline No & 2.0 & 0.000 & $2.4(1.8-3.1)$ & 2.1 & 0.000 & $3.8(36-40)$ \\
\hline Yes & 4.7 & & & 7.7 & & \\
\hline
\end{tabular}

OR : odds ratio; T2DM : type 2 diabetes mellitus

in the studies of 2007 and 2013. The prevalence of total cholesterol and LDL versus T2DM showed an increase in comparison with 5 years previously (2007). Similar, in the obese, body mass index and abdominal obesity carried a higher risk than in the non-obese. The prevalence of hypertension and mental-emotional disturbances in persons with T2DM increased within the 5year period (Table 2).

Riskesdas 2007 showed that the factors associated with T2DM, in addition to age, also comprised inadequate physical activity, consumption of sweets, and central obesity, after controlling for the variables gender, employment, and economic status. Higher age was strongly associated with incidence of T2DM. Persons with inadequate physical activity had a 1.9 fold higher risk (95\% CI:1.16-2.98) for T2DM, in comparison with those with adequate physical activity. Persons with central obesity had a 1.8 fold higher risk (95\% CI:0.99-3.10) in comparison with those without central obesity. The models had a 97.9 percent concordance with the true classification (Table 3 ).

The factors associated with T2DM in Riskesdas 2013 showed a 97.5 percent concordance with the true classification, except for inadequate physical activity with OR 2.4 (95\% 
Table 3. Determining factors of T2DM prevalence in 2007

\begin{tabular}{lccc}
\hline & $\begin{array}{c}\text { Adjusted } \\
\text { OR* }\end{array}$ & \multicolumn{2}{c}{$95 \mathrm{C}$ I for OR } \\
\cline { 3 - 4 } & & L ower & Upper \\
\hline Age group & & & \\
$25-34 \mathrm{yr}$ & 0.973 & 0.227 & 4.178 \\
$35-44 \mathrm{yr}$ & 4.121 & 1.216 & 13.964 \\
$45-54 \mathrm{yr}$ & 6.572 & 1.969 & 21.938 \\
$55-64 \mathrm{yr}$ & 11.136 & 3.352 & 37.000 \\
$65-74 \mathrm{yr}$ & 6.571 & 1.696 & 25.454 \\
$75+\mathrm{yr}$ & 1.000 & &. \\
Less active & 1.858 & 1.157 & 2.982 \\
Sweets & 0.431 & 0.273 & 0.681 \\
Centr al obesity & 1.759 & 0.998 & 3.100 \\
\hline
\end{tabular}

*Adjusted odds ratio controlled for variables in this table

Table 4. Determining factors of T2DM prevalence in 2013

\begin{tabular}{lccc}
\hline & \multirow{2}{*}{$\begin{array}{c}\text { Adjusted } \\
\text { OR* }\end{array}$} & \multicolumn{2}{c}{ 95 CI for OR } \\
\cline { 3 - 4 } & Lower & U pper \\
\hline Employed & 1.968 & 1.140 & 3.399 \\
Less active & 2.439 & 1.574 & 3.779 \\
Fruits-vegetables $<3$ & 0.650 & .421 & 1.005 \\
servings per day & & & \\
Smoking $\geq 200$ & 1.646 & 1.058 & 2.561 \\
cigarettes & & & \\
T otal cholesterol at & 0.453 & .212 & .969 \\
ri $\$$ & & & \\
LDL $\geq 200 \mathrm{mg} \%$ & 1.912 & 1.083 & 3.377 \\
Central obesity & 3.842 & 2.488 & 5.934 \\
Hypertension & 1.537 & .998 & 2.369 \\
Emoti cnal & 3.359 & 2.028 & 5.565 \\
di sturbances & & & \\
F asting glucose & & & \\
$100-125 \mathrm{mg} \%$ & 2.451 & 1.453 & 4.133 \\
$\geq 126 \mathrm{mg} \%$ & 9.603 & 5.165 & 17.853 \\
2 hr pp gducose & & & \\
$140<200 \mathrm{mg} \%$ & 1.233 & .746 & 2.038 \\
$\geq 200 \mathrm{mg} \%$ & 2.392 & 1.318 & 4.342 \\
Ex- and daily & 4.275 & 2.627 & 6.955 \\
sm oker & & & \\
\hline
\end{tabular}

*Adjusted odds ratio controlled for variables in this table
CI: 1,57-3,78) and central obesity with OR 3.8 (95\% CI: 2.49-5.93) (Table 4).

Active smokers and ex-smokers had a 4.3 fold higher risk (95\% CI: 2.63-6.96) of suffering from T2DM than non-smokers. Persons with emotional disturbances had a 3.4 fold higher risk (95\% CI: 2.03-5.57) of suffering from T2DM than those without mental emotional disturbances. Persons with inadequate physical activity (less active) had a 2.4 fold higher risk (95\% CI 1.573.78 ) than those with adequate physical activity. Persons with LDL cholesterol concentrations of $\geq 200 \mathrm{mg} / \mathrm{dl}$ had a 1.9 fold higher risk (95\% CI 1.08- 3.38) than those with LDL cholesterol concentrations of $<200 \mathrm{mg} / \mathrm{dl}$. Persons who smoked $\geq 200$ cigarettes had a 1.7 fold higher risk (95\% CI 1.06-2.56) than those who smoked <200 cigarettes. Persons with hypertension had a 1.5 fold higher risk (95\% CI 0.99-2.37) than those without hypertension. Persons with fasting blood glucose concentrations of $100-125 \mathrm{mg} / \mathrm{dl}$ had a 2.5 fold higher risk (95\% CI 1.45-4.23), but those with fasting blood glucose concentrations of $\geq 126$ $\mathrm{mg} / \mathrm{dl}$ had a 9.6 higher risk (95\% CI 5.17-17.85), whereas persons with 2-hour postload blood glucose concentrations of $\geq 200 \mathrm{mg} / \mathrm{dl}$ had a 2.4 fold higher risk (95\% CI 1.32-4.34), after controlling for the variables age, gender, and economic status.

\section{DISCUSSION}

Diabetes mellitus is a health problem that has most rapidly developed as a consequence of changes in life style. The prevalence of T2DM based on symptoms and blood glucose testing in persons aged $\geq 15$ years within a period of 5 years increased by $0.2 \%$ ( $2.3 \%$ in 2007 vs $2.5 \%$ in 2013).

The results of analysis showed that the determining factors of T2DM incidence are inadequate physical activity and central obesity in both 2007 and 2013. In the bivariate analysis of the 2007 data, the incidence of T2DM had a significant association with BMI scores of $\geq 27$ 
$\mathrm{kg} / \mathrm{m}^{2}$, smokers with a Brinkman index of $\geq 200$ cigarettes, LDL cholesterol concentrations of $\geq 200 \mathrm{mg} \%$, emotional disturbances, and hypertension, but had no significant association in the multivariate analysis.

However, a cohort study showed that central obesity was not a risk factor for the occurrence of new onset T2DM. ${ }^{(14)}$ The occurrence of new onset T2DM consists of increases in positive components of the metabolic syndrome. Even accumulation of triglycerides and free fatty acids may be associated with insulin resistance and beta cell dysfunction, so that monitoring of the blood glucose and triglyceride concentrations is very important in patients with T2DM, particularly those with central obesity. ${ }^{(15)}$

As a developing country with increasingly improved conditions, changes in dietary structure and life style result in altered food consumption, with more high caloric and high fat foods, while the requirement for physical exertion in occupational and daily activities has been reduced. These factors have led to increased obesity, thus causing a serious increase in the risks of comorbidity such as T2DM, heart disease, certain cancers, and shorter life expectancy. Longitudinal studies are in support of the fact that a diet high in fat and calories and inadequate physical activity are risk factors for obesity and that the diabetes incidence of 80$95 \%$ may be associated with obesity with fat distribution in the abdominal region. However, there are still many people who tolerate obesity. The underlying mechanism of genetic diversity in the oxidation of substrates is poorly understood, and may explain the occurrence of inter-individual variability in weight gain from life style. ${ }^{(16)}$ The negative influence of urbanization (living in metropolitan areas, having at least one car) on the level of activity, thus increasing the risk of T2DM, has been demonstrated in a Lebanese study in adults. ${ }^{(17)}$ In addition, the significantly decreased physical activity in the older age groups and in females does not reach the recommended targets, in comparison with males. ${ }^{(18)}$

A study in China showed that the prevalence of diabetes increased with increasing age and weight on the basis of body mass index. The prevalence of diabetes was also found to be higher in the urban than in the rural population. ${ }^{(19)}$ Furthermore, the cognitive factor of emotion, which affects dietary intake, may explain why some individuals are able to survive while having obesity. ${ }^{(20)}$ Whatever the reasons associated with it, obesity has contributed to non-communicable disease, especially diabetes mellitus. ${ }^{(21)}$

A study of the National Institutes of Health in the US found that moderate activity (30 minutes daily per week) or vigorous exercise (20 minutes three times weekly) is associated with overall reductions in the risk of death by $27 \%$ and $32 \%$, respectively. The study concluded that regular physical activity is the most important part of diabetes management planning and this finding underlines the importance of the regular application of physical activity as part of life style measures. ${ }^{(22)}$ Blomster et al. ${ }^{(23)}$ in their study concluded that moderate and vigorous activity are significantly associated with the reduction of cardiovascular and microvascular incidence, and of all-cause mortality in patients with T2DM. Another study showed a significant association of physical activity with age, gender, and ethnicity. With increasing age the level of physical activity was lower than recommended. Females (49\%) had less physical activity than recommended, in comparison with males $(62.4 \%){ }^{(19)}$

A cohort study involving 6,997 respondents showed that metabolic dysfunction increased the risk of T2DM. In the group with normal weight the risk was 4.7 fold higher, in the group with overweight the risk was 8.5 fold higher, and in the group with obesity 16.3 fold higher, in comparison with the group with normal weight without metabolic dysfunction. ${ }^{(24)}$ One of the limitations of this study was its cross-sectional design, which takes a momentary snapshot of the conditions of the subjects, so that it cannot as yet provide an answer to the causes and effects 
of central obesity in increasing the incidence of T2DM in urban adults.

\section{CONCLUSIONS}

Within a five-year period there was an increase in the prevalence of T2DM. The major risk factors associated with the prevalence of T2DM was central obesity. This may be of note in the institution of preventive and promotive measures to inhibit or prevent T2DM events, particularly in urban areas.

\section{ACKNOWLEDGEMENTS}

We wish to express our gratitude to the Head and Secretariat of the Health Research and Development Agency, Ministry of Health, Republic of Indonesia [Badan Penelitian dan Pengembangan Kesehatan, Kementerian Kesehatan RI] who provided us with the opportunity to perform further analyses of the data from Riskesdas 2007 and 2013. Thanks are also due to the data laboratory for providing the data for analysis.

\section{CONFLICT OF INTEREST}

The authors had no conflict of interest to declare in the conduct of this study.

\section{REFERENCES}

1. Guariguata L, Whiting DR, Hambleton I, et al. Global estimates of diabetes prevalence for 2013 and projections for 2035. Diabetes Res Clin Pract 2014;103:137-49.

2. International Diabetes Federation. IDF diabetes atlas, sixth edition, 2013. Available at: http:// www.idf.org/diabetesatlas/data-visualisations. Accessed May 30, 2015.

3. Yang SH, Dou KF, Song WJ. Prevalence of diabetes among men and women in China. $\mathrm{N}$ Engl J Med 2010;362:2425-6.

4. Routley VM. The emerging epidemic of type 2 diabetes: an Asian Pacific perspective. On The Risk 2011;27:72-6.
5. World Health Organization. Global status report on noncommunicable diseases 2014. Geneva: World Health Organization;2014.

6. Badan Penelitian dan Pengembangan Kesehatan. Riset kesehatan dasar Indonesia 2007: laporan nasional. Jakarta: Badan Penelitian dan Pengembangan Kesehatan;2008.

7. Badan Penelitian dan Pengembangan Kesehatan. Riset kesehatan dasar Indonesia 2013: laporan nasional. Jakarta: Badan Penelitian dan Pengembangan Kesehatan;2013.

8. Papatheodorou K, Banach M, Edmonds M, et al. Complications of diabetes. J Diabetes Res 2015. Article ID 189525, 5 pages.

9. Ruchat SM, Mottola MF. The important role of physical activity in the prevention and management of gestational diabetes mellitus. Diabetes Metab Res Rev 2013;29:334-46. doi: 10.1002/dmrr.2402.

10. Badan Penelitian dan Pengembangan Kesehatan. Riset Kesehatan Dasar Indonesia 2007: Pedoman Penatalaksanaan Biomedis. Jakarta: Badan Penelitian dan Pengembangan Kesehatan;2007.

11. Badan Penelitian dan Pengembangan Kesehatan. Riset Kesehatan Dasar Indonesia 2013: Pedoman Penatalaksanaan Biomedis.Jakarta: Badan Penelitian dan Pengembangan Kesehatan;2013.

12. The National Institute of Diabetes and Digestive and Kidney Disease (NIDDK). Diabetes overview. Bethesda: National Institute of Diabetes and Digestive and Kidney Disease; 2008.

13. Expert panel on detection, evaluation, and treatment of high blood cholesterol in adults. Executive summary of the third report of the national cholesterol education program (NCEP).JAMA 2001;285:2486-97. doi: 10.1001 /jama.285.19.2486.

14. Lee IT, Chiu YF, Hwu CM, et al. Central obesity is important but not essential component of the metabolic syndrome for predicting diabetes mellitus in a hypertensive family-based cohort. Results from the Stanford Asia-pacific program for hypertension and insulin resistance (SAPPHIRe) Taiwan follow-up study. Cardiovasc Diabetol 2012;11:43. doi: 10.1186/1475-284011-43.

15. Del Prato S. Role of glucotoxicity and lipotoxicity in the pathophysiology of type 2 diabetes mellitus and emerging treatment strategies. Diabetes Med 2009;26:1185-92.

16. Venables MC, Jeukendrup AE. Physical inactivity and obesity: links with insulin resistance and type 2 diabetes mellitus. Diabetes 
Metab Res Rev 2009;25 Suppl 1:S18-23. doi: 10.1002/dmrr.983.

17. Sibai AM, Costanian C, Tohme R, et al. Physical activity in adults with and without diabetes: from the 'high-risk' approach to the 'populationbased' approach of prevention. BMC Public Health 2013;13:1002. doi: 10.1186/1471-245813-1002.

18. Baldew SS, Krishnadath IS, Smits CC, et al. Self-reported physical activity behavior of a multi-ethnic adult population within the urban and rural setting in Suriname.BMC Public Health 2015;15:485. doi: 10.1186/s12889-0151807-1.

19. Yang W, Lu J, Weng J, et al. China national diabetes and metabolic disorders study group: $p$ revalence of diabetes among men and women in China. N Engl J Med 2010;362:1090-101. doi: 10.1056/NEJMoa0908292.

20. Galgani J, Ravussin E. Energy metabolism, fuel selection and body weight regulation. Int J Obes 2008;32:S109-19. doi: 10.1038/ijo.2008.246.
21. Australian Institute of Health and Welfare. Overweight and obesity;2015.Available at : http:/ /www.aihw.gov.au/overweight-and-obesity. Accessed April 7, 2005.

22. Zethelius B, Gudbjornsdottir S, Eliasson B, et al. Level of physical activity associated with risk of cardiovascular diseases and mortality in patients with type-2 diabetes: report from the Swedish National Diabetes Register. Eur J Prev Cardiol 2013;2047487313510893.

23. Blomster JI, Chow C K, Zoungas S, et al. The influence of physical activity on vascular complications and mortality in patients with type 2 diabetes mellitus. Diabetes Obes Metab 2013; 15:1008-12.

24. Franssens BT, van der Graaf Y, Kappelle LJ, et al. Body weight, metabolic dysfunction, and risk of type 2 diabetes in patients at high Risk for cardiovasculare events or with manifest cardiovascular disease: acohort study. Diabetes Care 2015;38:1945-51. 